\title{
Tantangan dan Antisipasi Pendidikan Agama Islam di Tengah Arus Globalisasi
}

\author{
Pandu Hyangsewu ${ }^{1 *}$ \\ ${ }_{1}^{1}$ Program Studi Ilmu Pendidikan Agama Islam, Fakultas Pendidikan Ilmu Pengetahuan Sosial, Universitas Pendidikan Indonesia, \\ Bandung, Indonesia
}

\section{ARTICLE INFO}

\section{Keywords}

Antisipasi, Globalisassi

Tantangan, Pendidikan Agama Islam

\section{*Correspondence \\ hyangsewu@upi.edu}

\section{Article History}

Received 22 Mei 2019

Accepted 24 Juni 2019

Published online 7 Juli 2019

\begin{abstract}
Perkembangan zaman yang begitu cepat tidak dapat dipungkiri lagi akan mempengaruhi kehidupan manusia. Globalisasi yang terjadi sudah mengubah pola kehidupan manusia, dimana dampaknya bukan hanya efek positif melainkan dapat menghadirkan efek negatif pula. Pengaruh globalisasi saat ini sudah melarutkan nilai-nilai Pendidikan Agama Islam mulai dari tatanan kebudayaan, adat istiadat dan nilai-nilai luhur ajaran Islam. Padahal Pendidikan Agama Islam mempunyai peranan yang penting dalam kehidupan manusia sebagai pendidikan yang bersifat mutlak, Pendidikan Agama Islam perlu dioptimlkan sebagai usaha pengembangan potensi diri agar tidak mudah terjerumus dalam gelapnya kehidupan di era globalisasi. Untuk itu, perlu diketahui berbagai macam tantangan dan antisipasi yang dapat dilakukan melalui Pendidikan Agama Islam di tengah arus globalisasi. Tujuan artikel ini untuk menjelaskan permasalahan Pendidikan Agama Islam saat ini dan bagaimana cara mengantisipasinya dalam menghadapi era globalisasi. Data dalam tulisan ini menggunakan studi literatur yang dianalisis secara deskriptif. Hasil penelitian menunjukkan bahwa globalisasi dapat menjadi peluang sekaligus tantangan bagi Pendidikan Agama Islam. Arus globalisasi bukan sebagai kawan ataupun lawan bagi Pendidikan Agama Islam, melainkan sebagai dinamisator. Ketika Pendidikan Agama Islam tidak mengikuti arus globalisasi maka akan mengalami hambatan intelektual. Sebaliknya, ketika Pendidikan Agama Islam mengikuti arus globalisasi tanpa berlandaskan pada keislaman maka akan terlindas dan tidak tahu arah. Oleh karena itu, Pendidikan Agama Islam harus memposisikan diri di tengah arus globalisasi dalam arti yang sesuai dengan pedoman dan ajaran nilai-nilai Islam agar dapat diadopsi dan dikembangkan pada kehidupan manusia
\end{abstract}

The development of the era is so fast undeniably it will affect human life, Globalization has changed the pattern of human life, where the impact is not only a positive effect but can also bring adverse consequences. The influence of globalization now has dissolved the values of Islamic religious education, starting from the social order, customs, and ethical values of Islamic teachings. Even though Islamic education has an essential role in human life, as a comprehensive education, Islamic religious education needs to be optimized as an effort to develop self-potential, so as not to fall prey to the darkness of life in the era of globalization. For this reason, we need to know various kinds of challenges and anticipation that can be done, through Islamic religious education amid globalization. The purpose of this article is to explain the current issue of Islamic religious education and how to anticipate it in the face of the era of globalization. The data in this paper uses literature studies which are analyzed descriptively. The results of the survey show that globalization can be an opportunity as well as a challenge for Islamic religious education. The current of globalization is neither a friend nor an opponent for Islamic religious education but as a dynamism. When Islamic religious education does not follow the flow of globalization, it will experience mental obstacles. Conversely, when Islamic religious education follows the flow of globalization without being, based on Islam. It will get run over and don't know the direction. Therefore, Islamic religious education must position itself in the midst of globalization. in a sense that is by the guidelines and teachings of Islamic values so that they can be adopted and developed in human life

\section{PENDAHULUAN}

Zaman yang semakin maju membuat manusia harus bisa menyesuaikan dengan arus perkembangan zaman. Perkembangan zaman yang begitu cepat tidak dapat dipungkiri lagi akan mempengaruhi pola kehidupan manusia pada umumnya dan pendidikan pada

(C) 2019 by the authors; Association of Indonesian Moslem Scholar, Hannover, Germany. This is an Open Access article distributed under the terms of the Creative Commons Attribution-ShareAlike 4.0 International License. (https://creativecommons.org/licenses/by-sa/4.0/), which permits unrestricted use, distribution, and reproduction in any medium, provided the original work is properly cited. 
khususnya. Kehadiran era globalisasi ini menimbulkan berbagai macam efek, bukan hanya efek positif melainkan dapat menghadirkan efek negatif pula. Pendidikan sebagai suatu proses pembentukan kemampuan dasar manusia yang bersifat fundamental, baik menyangkut daya fikir (intelektual) maupun daya perasaan (emosional) harus mampu menyeimbangkannya di tengah arus globalisasi. Globalisasi memberikan tantangan juga peluang dalam dunia pendidikan yang akan menggoyahkan tatanan kebudayaan, adat istiadat, dan nilai-nilai luhur ajaran Islam (Suriana, 2014)

Pendidikan Agama Islam mempunyai peranan yang penting dalam kehidupan manusia sebagai pendidikan yang bersifat mutlak. Pendidikan Agama Islam sebagai bagian dari sistem pendidikan nasional harus mampu memainkan peranan yang sangat penting dalam tatanan kehidupan masyarakat untuk menghadapi era globalisasi (Pewangi, 2016). Sistem Pendidikan Agama Islam mencakup seluruh aspek kehidupan yang dibutuhkan oleh hamba Allah SWT, sebagaimana Islam telah menjadi pedoman bagi seluruh aspek kehidupan manusia, baik duniawi maupun ukhrawi (Setiyadi, 2012)

Pengaruh globalisasi saat ini sudah melarutkan nilai-nilai pendidikan agama islam. Untuk itu perlu dioptimalkannya Pendidikan Agama Islam sebagai suatu usaha pengembanganpotensi diri agar tidak mudah terjerumus dalam gelapnya kehiupan di era globalisasi. Semua persoalan yang memperlemah kondisi umat harus melalui upaya strategis dalam memperkuat sumber daya umat Islam dari seluruh aspek. Salah satu upaya strategis dalam peningkatan kualitas umat adalah dengan membenahi sistem pendidikan yang secara langsung berkaitan dengan pengembangan sumber daya manusia.

Menurut Mahsun (2013) ada beberapa hal yang bisa dilakukan dalam peningkatan sistem Pendidikan Agama Islam dan kecenderungan masa depan global. Pertama, umat Islam harus mampu memanfaatkan sarana teknologi sebagai alat perjuangan jihad nya artinya sarana teknologi perlu dijadikan sebagai alat perjuangan umat Islam dalam meningkatkan kualitas pendidikan dan bukan sebaliknya sebagai penghalang bagi kreativitas berpikir dan berbuat bagi perubahan untuk kemajuan. Kedua, umat islam harus secara terus menertu meningkatkan sumber daya manusia yang berkualitas IPTEK dan IMTAQ secara bersamaan, atau peningkatan diri ke araha kekokohan spiritual, moral dan intelektual. Ketiga, proses modernisasi adalah sesuatu yang meniscayakan bagi perombakan sistem Pendidikan Agama Islam, mulai dari paradigm, konsep kerangka kerja dan evaluasi.

Oleh karena itu globalisasi disebut sebagai tantangan dan juga peluang bagi setiap manusia karena dengan adanya globalisasi manusia akan saling berhubungan satu sama lain, tidak hanya dalam cakupan wilayah lokal, melainkan mendunia. Maka sudah seharusnya Pendidikan Agama Islam berupaya untuk mengembangkan diri peserta didik tidak hanya sukses dengan IMTAQnya saja, tetapi sukses juga dalam menghadapi dunia global dengan IPTEKnya. Berdasarkan latar belakang masalah tersebut, maka dirumuskan beberapa masalah, antara lain adalah bagaimana hakikat pendidikan agama islam dan globalisasi; probelamtika apa sajakah yang dihadapi pendidikan gama islam di era globalisasi?; bagaimana penerapan Pendidikan Agama Islam di sekolah?; dan bagaimana antisipasi Pendidikan Agama Islam dalam menghadapi era globalisasi? Kajian ini merupakan bentuk kajian studi litearur. Data diperoleh dari literature yang berbicara tentang Pendidikan Agama Islam dan kaitannya dengan tantangan globalisasi serta anitisipasi yang perlu dilakukan untuk menghadapi era globalisasi.

\section{HASIL PENELITIAN DAN PEMBAHASAN}

\subsection{Hakikat Pendidikan Agama Islam}

Pendidikan Agama Islam ialah upaya mendidikkan agama islam dan nilai-nilai agar menjadi way of life atau sebagai sistem hidup seseorang dalam bentuk segenap kegiatan yang dilakukan seseorang untuk membantu seseorang atau peserta didik dalam menanamkan atau menumbuh kembangkan ajaran islam dan nilai-nilainya untuk dijadikan sebagai pandangan hidup yang kemudian dikembangkan dalam kehidupan sehari-hari (Siswati, 2018). Sementara di dalam peraturan menteri Agama Republik Indonesia Nomo 13 Tahun 2014 tentang pendidikan Kegamaan Islam dijelaskan bahwa pendidikan keagmaan islam adalah pendidikan yang mempersiapkan peserta didik untuk dapat menjalankan peranan yang menuntut penguasaan pengetahuan tentang ajaran agama Islam dan /atau menjadi ahli ilmu agama islam dan mengamalkan ajaran agama Islam.

Secara sederhana pendidikan agama islam dapat diartikan sebagai pendidikan yang didasarkan pada nilai-nilai ajaran islam yang betujuan untuk menyiapkan peserta didik menjadi manusia yang hidup bahagia di dunia maupun di akhirat dengan berdasarrkan ajaran yang tercantum dalam Al-Quran dan Al-Hadits serta dalam pemikiran para ulama dan dalam praktik sejarah umat islam. Sehingga dengan pendidikan agama tersebut dapat mengontrol segala tingkah lakunya di dunia dan dapat menyelamatkan hidupnya kelak di akhirat.

\subsection{Hakikat Globalisasi}

Globalisasi beraal dari kata globe yang berarti bola bumi (Dacholfany, 2015). Istilah ini digunakan karena akselarasi penyebaran informasi yang luar biasa. Kata globalisasi sering dipahami dengan adanya kemajuan teknologi informasi dan komunikasi yang dirasakan masyarakat global, baik di daerah pedesaan hingga perkotaan. Globalisasi saat ini telah menyebar ke seluruh dunia dalam semua bidang kehidupan, baik dalam bidang pendidikan, politik, ekonomi, sosial budaya bahkan agama (Bahri, 2015: 6566).

Globalisasi itu sendiri telah membawa masyarakat dunia pada sebuah tatanan budaya global. Terlebih lagi tidak ada manusia yang dapat terhindar dari arus globalisasi ini kecuali ia tidak menjadlin kontak dengan orang lain sama sekali atau tidak mengikuti perkembagan zaman dan hanya hidup apa adanya. Globalisasi merupakan suatu proses dimana antar individu, antar kelompok dan antar Negara saling berinteraksi, bergantung, terkait dan memengaruhi satu sama lain yang melintasi batas Negara, yakni integrasi bangsa-bangsa dalam satu sistem global. Isu-isu yang berkembang akibat adanya globalisasi diantaranya semacam civil society, hak asasi manusia, liberalisasi, multikulturalisme dan sebagaianya yang semakin berkembangan dengan pesat menjangkau pelosok-pelosok Negara. Menurut A. Ubaedillah dan Rozak (2003), globalisasi secara umum adalah sebuah gambaran tentang semakin ketergantungan diantara sesama masyarakat dunia baik budaya maupun ekonomi. Istilah globalisasi juga sering dihubungkan dengan sirkulasi gagasan, bahasa, dan budaya populer yang melintasi batas negara. Fenomena global ini acap kali 
disederhanakan oleh kalangan ahli sebagai gejala kecenderungan dunia menujusebuah perkampungan global (global village) dimana interaksi manusia berlangsung tanpa halangan batas geografis. Hal ini tentunya bagian tak terpisahkan dari kemajuan teknologi informasi yang menyediakan fasilitas manusia modern untuk menjalin komuniksasi secara murah dan mudah. Pada saat yang sama, isu-isu dunia di bidang politik, ekonomi, demokrasi, dan hak asasi manusia (HAM) dengan begitu cepat dapat memengaruhi situasi yang terjadi di suatu negara (Rozak, 2003).

Yusuf Qardhawi (2001) dalam buku Islam dan Globalisasi Dunia mengatakan bahwa globalisasi mengandung arti menghilangkan batas-batas kenasionalan dalam bidang ekonomi (perdagangan) dan membiarkan sesuatu bebas melintas dunia dan menembus level internasional, sehingga terancamlah nasib suatu bangsa atau negara. Ditegaskan pula Yusuf Qardhawi (2001) dalam buku Ummat Islam menyongsong Abad 21, globalisasi berarti pula eliminasi batasbatas teritorial antara suatu bangsa dengan bangsa yang lain, antara tanah air yang satu dengan yang lain, antara kebudayaan yang satu dengan yang lain.

\subsection{Problematika Pendidikan Agama Islam di Era Globalisasi}

Globalisasi memiliki pengaruh yang sangat besar bagi kehidupan manusia dalam berbagai aspek kehidupan baik dari aspek ekonomi, sosial, olitik, budaya, agama dan pendidikan. Globalisasi telah mengubah kehidupan sehari-hari dan memberikan dampak bagi masyarakat. Dari segi aspek pendidikan, globalisasi telah bepengaruh terhadap penyelenggaraan pendidikan, baik terhadap tujuan, proses hubungan peserta didik dan pendidik, etika, metode maupun yang lainnya. Contoh pengaruh dari segi kurikulumnya, lebih mengarah pada bagaimana hal-hal yang materialistic itu dapat dicapai. Dalam hal ini belajar lebih berfokus pada aspek penguasaan ilmu (kognitif) belaka ketimbang bagaimana seorang siswa memiliki sikap yang sesuai dengan nilai-nilai Islam (Baharudin, 2011).

Dijelaskan lebih rinci mengenai problematika pendidikan islam di sekolah dalam menghadapi era glibalisasi (Siswati, 2018) yaitu: (1) dalam bidang teologi, ada kecenderungan mengarah pada faham fatalistic; (2) dalam bidang akhlak, orientasinya masih pada aspek sopan santun dan belum dipahami sebagai keseluruhan kesatuan manusia beragama; (3) dalam bidang ibadah, diajarkan sebagai kegiatan rutin agama dan tidak ditekankan sebagai proses pembentukan kepribadian; (4) dalam bidang hukum fiqh cenderung dipelajari sebagai tata aturan yang tidak akan berubah sepanjang masa, serta kurang memahami dinamika dan jiwa hukum Islam; (5) agama islam diajarkan cenderung sebagai dogma yang kurang mengembangkan rasionalitas dan kecintaan pada ilmu pengetahuan; dan (6) orientasi membaca al-Quran masih cenderung pada kemampuan membaca teks, belum mengarah pada pemahaman arti dan penggalian makna.

Dalam menuju era globalisasi, program pendidikan harus diperbaharui, dibangun kembali atau dimodernisasi sehingga dapat memnuhi harapan dan fungsi yang dipikulkan kepadanya. Dengan dihadapi berbagai macam tantangan, pendidikan islam harus melakukan perenungan dan penelitian kembali apa yang harus diperbuat untuk mengatasi berbagai problematika tersebut, seperti menggunakan model-model pendidikan agama Islam seperti apa yang perlu ditawarkan di masa depan.

Terdapat beberapa problematika Pendidikan Agama Islam di Era Globalisasi ini diantaranya ada beberapa faktor: (1) Masalah besar yang dihadapi dunia pendidikan islam adalah dikotomi dalam beberapa aspek yaitu antara Ilmu Agama dengan Ilmu Umum, antara Wahyu dengan Akal setara antara Wahyu dengan Alam. Munculnya problem dikotomi dengan segala perdebatannya telah berlangsung sejak lama. Boleh dibilang gejala ini mulai tampak pada masa-masa pertengahan. Menurut Rahman, dalam melukiskan watak ilmu pengetahuan islam zaman pertengahan menyatakan bahwa, muncul persaingan yang tak berhenti antara hukum dan teologi untuk mendapat julukan sebagai mahkota semua ilmu. (2) Menurut Syed Alatas menyatakan bahwa, kemampuan untuk mengatasi berbagai permasalahan, mendefinisikan, menganalisis dan selanjutnya mencari jalan keluar/pemecahan masalah tersebut merupakan karakter dan sesuatu yang mendasar kualitas sebuah intelektual. Ia menambahkan, ciri terpenting yang membedakan dengan non-intelektual adalah tidak adanya kemampuan untuk berfikir dan tidak mampu untuk melihat konsekuensinya, dan (3) Persoalan besar lainnya yang menjadi penghambat kemajuan dunia pendidikan islam ialah rendahnya semangat untuk melakukan penelitian/penyelidikan (Wahid, 2008).

Pendidilan Agama Islam masih dan akan terus sanggup menghadapi tantangan arus globalisasi yang terjadi sekarang ini, karena pendidikan agama islam sendiri sangat berperan penting sebagai filter dan akan terus meningkatkan mutu dan efisiensi pendidikan. Pendidikan agama islam harus mampu menguasai ilmu-ilmu yang relevan dengan perkembangan zaman, yang sejatinya dapat mengukuhkan keimanan dan memotivasi lembaga Pendidikan Islam untuk membekali peserta didiknya agar nantinya tidak terjerumus dalam arus globalisasi (Suriana, 2014).

\subsection{Penerapan Pendidikan Agama Islam di Sekolah}

Strategi penerapan pembelajaran Pendidikan Agama Islam di sekolah dapat dilihat dari tiga tataran implemntasi (Bagir, 2005), yakni konsep konseptual, konsep operasional dan konsep institusional. Dalam tataran konseptual, integrasi pendidikan nilai dapat diwujudkan melalui perumusan visi, misi, tujuan dan program sekolah. Sedangkan tataran operasional, strategi penyampaian nilainilai di sekolah menggunakan strategi eksplisit. Nilai-nilai yang terkandung dalam materi pembelajaran Pendidikan Agama Islam disampaikan secara jelas, tegas, dan tersurat. Dalam strategi ini, fasilitator kelas langsung meminta kepada siswa untuk membaca, meneliti, mengkaji, nilai-nilai yang terintegrasi, kemudian mendeskripsikan dan menyimpulkan nilai-nilai tersebut.

Sementara itu, dalam tataran institusional, strategi pengintegrasian pendidikan nilai di sekolah adalah dengan cara pembentukan institution cultural yang mencerminkan paduan antara nilai dan pembelajaran. Proses pembelajaran Pendidikan Agama Islam yang dilakukan meliputi tujuan, materi, metode, media dan sumber belajar. Tujuan pembelajaran Pendidikan Agama Islam di sekolah adalah agar siswa mengetahui dan memahami nilai-nilai Islami sehingga mereka memiliki akhlak mulia. Selain itu, dengan belajar Pendidikan Agama Islam mereka diharapkan dapat memiliki pengetahuan dan pemahaman tentang aqidah, AlQuran dan Al Hadits, fiqh, dan sejarah yang bisa menjadi bekal dalam kehiupan mereka sehari hari.

Metode pembelajaran Pendidikan Agama Islam di sekolah-sekolah menggunakan metode ceramah bervariasi, tanya jawab, diskusi, bermain peran, penghargaan dan hukuman, bercerita penugasan dan metode observasi. Pembelajaran Pendidikan Agama 
Islam di sekolah-sekolah sudah sangat maju karena metode dan media yang digunakan sudah mengikuti perkembangan zaman seiring berkembangnya era globalisasi, seperti menggunakan internet dan teknologi untuk menunjang pembelajarannya. Tapi realita zaman sekarang Pendidikan Agama Islam hanya sekedar mata pelajaran biasa, para siswa mempelajarai Pendidikan Agama Islam hanya untuk mendapatan nilai saja tanpa memahami nilai-nilai yang terkandung dalam pelajaran Pendidikan Agama Islam

Pendidikan moral adalah salah satu nilai yang sangat penting di dalam pelajaran Pendidikan Agama Islam . Rendahnya antusiasme Pendidikan Agama Islam di kalangan murid-murid menyebabkan kurangnya pendidikan moral karena Pendidikan Agama Islam adalah unsur terpenting dari pendidikan moral. Maka terciptalah beberapa perilaku buruk seperti: ketidakjujuran dalam ujian, tidak sopam, berkata kasar, berkelahi dan sebagainya. Kenyataan ini menunjukkan bahwa pendidikan moral tidaklah sejalan semestinya.

\subsection{Antisipasi Pendidikan Agama Islam di Tengah Arus Globalisasi}

Pendidikan Agama Islam memiliki peluang yang sangat besar untuk menyebarkan islam lebih luas lagi dalam era globalisasi. Hal ini bisa dilihat dari berbagai fenomena dewasa ini (Bakhri 2015) mengemukakan beberapa hal yang dapat dilakukan dalam usaha meningkatkan gairah Pendidikan Agama Islam, yaitu sebagai berikut: (1) meningkatkan muru pendidikan agama islam seperti metode dan materi pembelajaran agama islam, sumber daya guru agama, fasilitas kegiatan keagamaan, indtrumen penunjang pendidikan agama islam (ekstrakulikuler keagamaan, school culture); (2) langkah strategis pendidikan agama silam di era globalisasi yaitu: (a) penyempurnaan kurikulum pendidikan agama agar materi pelajarannya mencapai komposisi yang proporsional dan fungsional tetapi tidak membebani siswa; (b) memadukan materi agama dengan pendidikan budi pekerti mialnya PKN atau pelajaran lainnya yang terkait hal ini juga dapat mengikis dikotomi ilmu; dan (c) menciptakan kondisi agamis di lingkungan sekolah.

Berdasarkan hal tersebut globalisasi dapat menjadi peluang sekaligus tantangan bagi Pendidikan Agama Islam. Arus globalisasi bukan sebagai kawan ataupun lawan bagi pendidikan agama islam, melainkan sebagai dinamisator. Ketika Pendidikan Agama Islam tidak mengikuti arus globalisasi, maka akan mengalami hambatan intelektual. Sebaliknya, ketika pendidikan agama islam mengikuti arus globalisasi tanpa berlandas pada keislaman maka akan terlindas dan tidak tahu arah. Oleh Karena itu Pendidikan Agama Islam harus memposisikan diri di tengah arus globalisasi dalam arti yang sesuai dengan pedomand an ajaran nilai-nlai islam agar dapat diadopsi dan dikembangkan pada kehidupan manusia.

Untuk itu Dalam menuju era globalisasi, indonesia harus melakukan reformasi dalam proses pendidikan, dengan tekanan menciptakan sistem pendidikan yang lebih komprehensif, dan fleksibel, sehingga para lulusan dapat berfungsi secara efektif dalam kehidupan masyarakat global demokratis. Untuk itu, pendidikan harus dirancang sedemikian rupa yang memungkinkan para peserta didik mengembangkan potensi yang dimiliki secara alami dan kreatif dalam suasana penuh kebebasan, kebersamaan, dan tanggung jawab. Salah satu alternatif yang dapat dilakukan adalah mengembangkan pendidikan yang berwawasan global (Zamroni, 2000). Pendidikan Agama Islam harus diorientasikan untuk menciptakan "kesadaran kritis" masyarakat. Sehingga dengan kesadaran kritis ini akan mampu menganalisis hubungan faktor-faktor sosial dan kemudian mencarikan jalan keluarnya. Selain itu juga adanya proses humanisasi dalam Pendidikan Agama Islam dimaksudkan sebagai upaya mengembangkan manusia sebagai makhluk hidup yang tumbuh dan berkembang dengan segala potensi (fitrah) yang ada padanya. Dan Pendidikan Agama Islam harus dikembalikan kepada fitrahnya sebagai pembinaan akhlaq al-karimah, dengan tanpa mengesampingkan dimensidimensi penting lainnya yang harus dikembangkan dalam institusi pendidikan, baik formal, informal, maupun nonformal (Tantowi, 2009).

\section{KESIMPULAN}

Berdasarkan temuan dan hasil pembahasan tersebut maka dapat ditarik kesimpulan sebagai berikut: Hakikat pendidikan agama islam diartikan sebagai pendidikan yang didasarkan pada nilai-nilai ajaran islam yang bertujuan untuk menyiapkan peserta didik menjadi manusia yang hidup bahagia di dunia maupun di akhirat dengan berdasarkan ajaran yang tercantum dalam Al-Quran dan Al-Hadits serta dalam pemikiran para ulama dna dalam praktik sejarah umat islam. Sedangkan hakikat globalisasi merupakan suatu proses dimana antar individu, antar kelompok dan antar Negara saling berinteraksi, bergantung, terkait dan memengaruhi satu sama lain yang melintasi batas Negara.

Problematika pendidikan agama islam yang terjadi di tengah arus globalisasi ini terdiri dari tiga garis besar, yaitu kemajuan ilmu pengetahuan dan teknologi yang menyebabkan generasi muslim harus memahami dan menguasai teknologi agat tidak tertinggal; demokratisasi dimana pendidikan agama islam yang tadinya bersifat sentralistik seragam dan dependen dirubah menjadi lebih otonom, beragam dan independen; serta pergeseran nilai dan moral budaya dibuktikan dengan budaya barat yang lebih unggul daripada budaya islam sehingga banyak yang lebih tertarik pada budaya barat dan sedikit demi sedikit melupakan budaya Islam

Penerapan pendidikan agama islam di sekolah dapat dilihat dari tiga tataran, yakni konsep konseptual, konsep operasional, dan konsep institusional. Proses pembelajaran PAI yang dilakukan meliputi tujuan, materi, metode, media dan sumber belajar. Tujuan pembelajaran PAI di sekolah adalah agar siswa mengetahui dan memahami nilai-nilai Islam sehingga mereka memiliki akhlak mulia

Berdasarkan problematika yang ada, strategi yang perlu dilakukan PAI untuk mengantisipasi dalam menghadapi era globalisasi, yaitu: meyelesaikan persoalan dikotomi, dengan menerima pendidikan umum (modern) dan mencoba mengisinya dengan konsep-konsep ajaran islam, revitalisasi tujuan dan fungsi lembaga pendidkan Islam; dan reformasi kurikulum dan materi karena materi pendidikan agama islam terlalu didominasi masalah-masalah yang bersifat normatif.

\section{Daftar Pustaka}

Bagir, Z. A. (2005). Integrasi Ilmu dan Agama: Introspeksi dan Aksi. Bandung: PT Mizan Pustaka Baharudin. (2011). Pendidikan Islam dan Isu-Isu Sosial, Yogyakarta: Kurnia Kalam Semesta. Bakhri, A. (2015). Tantangan Pendidikan Agama Islam di Madrasah pada Era Globalisasi. Jurnal Madaniyah, 8, 63-86. 
Dacholfany, M. I. (2015). Reformasi Pendidikan Islam dalam Menghadapi Era Globalisasi: Sebuah Tantangan dan Harapan. AKADEMIKA, 20(1), 173-194.

Mahsun, A. (2013) Pendidikan Islam dalam Arus Globalisasi: Sebuah kajian Deskriptif Analitis. Episteme, 8(2), $259-278$.

Peraturan Menteri Agama Republik Indonesia Nomor 13 Tahun 2014 Tentang Pendidikan Keagamaan Islam.

Pewangi, M. (2016). Tantangan Pendidikan Islam di Era Globalisasi, Jurnal Tarbawi, 1(1), 1-11.

Qardhawi, Y. (2001). Islam dan Globalisasi Dunia, Jakarta: Pustaka al-Kautsar.

Qardhawi,Y. (2001). Ummat Islam menyongsong Abad 21. Solo: Era Intermedia.

Rozak, A. (2003). Pendidikan Kewarganegaraan. Jakarta: Kencana.

Setiyadi, A. C. (2012). Pendidikan Islam dalam Lingkaran Globalisasi. Jurnal At-Ta'dib, 7(2), 245-256.

Siswati, V. (2018). Pesantren Terpadu sebagai Solusi Problematika Pendidikan Agama Islam di Era Globalisasi, Jurnal Pendidikan Islam Indonesia, 2(2), 123-138.

Suriana. (2014), Pendidikan Islam di Era Globalisasi: Menggapai Peluang, Menuai Tantangan, Jurnal Mudarrisuna, 4(2), $256-375$.

Tantowi, A. (2009). Pendidikan Islam di Era Transformasi Global. Semarang : Pustaka Rizki Putra.

Wahid, A. (2008). Isu-isu Kontemporer Pendidikan Islam. Semarang: Need's Press.

Zamroni, (2000). Paradigma Pendidikan Masa Depan. Jogjakarta: Gigraf Publishing. 